\title{
Understanding Regime Divergence in the Post-Uprising Arab States
}

\author{
Raymond Hinnebusch ${ }^{1}$
}

\begin{abstract}
Despite the fact that democracy was a main demand of the protestors who spearheaded the Arab uprisings, five years later only Tunisia qualifies as democratic while elsewhere the outcomes have been either authoritarian restoration or failing states. This paper seeks to understand these three divergent trajectories in the post-Uprising Arab states, with Tunisia, Egypt and Syria taken as representative of each.
\end{abstract}

\section{The Post-Uprising Literature and Historical Sociology}

For several decades, scholarship on MENA was caught between the democratization paradigm (DT) that, anticipating democratic transformation, had little interest in understanding actually existing nondemocratic polities and the authoritarian resilience (AR) approach, which saw the region as relatively immune to democratization. Both dichotomizing approaches obstructed understanding the Arab Uprising: the AR school failed to anticipate it and the DT school cannot easily explain the "modest [democratic] harvest" (Brownlee et al. 2013) of the post-uprising period (Valbjorn 2015). Nor can either readily explain the patent variation in outcomes.

To be sure, an important body of literature is accumulating on the causes and consequences of the Uprisings, although it still struggles to escape from the DT-AR dichotomy (Valbjorn 2015). Thus, much of the earliest work sought to understand what had been missed by the AR literature after authoritarian regimes unexpectedly succumbed to the uprising and focused on how anti-regime mobilization had succeeded after years of public quiescence, sometimes resurrecting the expectations of DT (Aarts et.al; 2012; Tripp 2014; Leenders 2013; Durac 2015). As democratization stalled, AR-like work speculated as to whether certain types of authoritarianism-notably "Sultanism"--made peaceful democratization less likely (Stepan and Linz 2013). Most work remained at the level of agency-the strategies of elites or opposition--and the handful of those examining the structural context were more concerned about how it had generated the grievances behind revolt than with how it might bias post-uprising trajectories (Aschar 2103, Heyderian 2104). Work on the international impact on the uprisings tended to focus on the diffusion of democratic transitions (Abushouk 2016) or on the counter-effect of inter-authoritarian mutual support (Leenders 2016), with far less attention to how competitive intervention by several rival powers with opposing projects might affect outcomes. These works also tended to privilege certain aspects over others; as such, what is now needed is to systematically and comparatively bring these dimensions together and to focus on their combined impact on post-uprising trajectories (Hinnebusch 2016).

The Historical Sociology (HS) tradition is particularly suited to this effort if one takes it to be a very broad church embracing different strands, each of which addresses part of the equation needed to adequately understand post-Uprising trajectories. HS varieties that focus on agency include the power elite studies of classical political sociology, neo-Weberianism approaches to authority creation and social movement theory on opposition agency. Those focusing on the broader structural contexts include Marxist-inspired political economy work and International Historical Sociology's exposure of the historic co-constitution of states and states systems (Hinnebusch 2014).

HS (HS) has several conceptual advantages over its main rivals, DT and AR, in understanding post-uprising trajectories. First, unlike DT, HS does not assume a universal democratic end point of development; on the contrary, classical political sociology's "iron law of oligarchy" underlines the resilience of elite rule and the advantages elites have in sustaining or restoring control (Michels 1966, Mosca 1939). On the other hand, HS does not, either, assume elite strategies will always prevail, with social movement theory identifying the conditions in which masses-or more precisely "counter-elites"-can break through elite containment. As such, rather than DT's linear "progress" toward democratization or AR's authoritarian exceptionalism, we should expect on-going power struggles of oligarchic and democratic tendencies and cycles in which one or the other seems dominant in different periods.

Second, while DT and AR over-stress agency (of elites or counter-elites,) HS stresses the interaction of agency and structure-how the structural context within which power struggles play out affects which tendency prevails at given periods. Completely missed in the DT-AR debate (being largely

\footnotetext{
${ }^{1}$ Raymond Hinnebusch is Professor of International Relations and Middle East Politics at the University of St Andrews and may be contacted at rh10@st-andrews.ac.uk
} 
innocent of Marxist thinking) is the decisive role of political economy structures and strategies in shaping the political inclusion and exclusion of social forces that gives regimes their essential character and which only favour democratization under quite specific conditions. Further, IHS, particularly as exemplified in the work of Tilly, shows how the co-constitution of states and states systems amidst international power struggles drives outcomes.

Third, instead of the dichotomization of outcomes typical of DT and AR (democratic or authoritarian), Weberian HS sees a much greater variety of outcomes. Furthermore, while DT simply assumes the state as unproblematic, HS sees state building as a historic product (Huntington 1968) that can be reversed, as indeed was shown by the high incidence of state failure in the post-uprising Arab world. HS, with its focus on state formation, is particularly suited to examine how, when states fail, rivals compete to fill the space via "competitive regime-building." For DT's teleology HS substitutes path dependency, as historically successful authority building practices get reproduced: in MENA these were identified by the father of sociology, Ibn Khaldun, and systematized by Weber, e.g. charismatic movements or neo-patrimonial rule.

This paper tries to link these three main factors, agency, structure and outcome. 1) Agency: it combines several HS approaches to understand agency in Uprising-unleashed power struggles, notably Social Movement theory and Weberian power-building approaches. 2) Structure: it brings in approaches that explain how longue duree political economy macro-processes (Marxism) and international power struggles (International Historical Sociology) condition the outcomes of shorter term struggles. 3) Outcomes: and it links these to Weberian approaches that help understand the considerable variability of outcomes. Bringing these various strands of HS together might best be called "Complex Historical Sociology." The following framework further elucidates these key variables and their inter-relations.

\section{Framework of Analysis: Thru the Lens of "Complex Historical Sociology"}

\section{The Depth of Change}

The first dimension that shapes trajectories is the depth or scale of change initiated by the onset of the Uprisings, that is how much "political space" it opens for change via regime/opposition contestationover the streets, elite circulation, and territorial control. This is most immediately determined by the interaction between the capacity of opposition movements to spur anti-regime mobilization and of ruling elites to resist or adapt to this challenge.

Social Structure and Mobilization: Social structure, particularly the relation between class and communal identities, shaped variations in the depth and breadth of anti-regime mobilization in uprising states, and also affected whether thereafter opposition movements remained sufficiently united to displace the establishment or were coopted, fragmented or marginalized.

Political Structure and regime resilience: regime strategies and capacity to adapt to anti-regime mobilization was a function of the degrees of ruling elite unity and bureaucratic (co-optative and coercive) "infrastructural" capacity.

The interaction between anti-regime mobilization and regime resilience, plus degrees of historic "stateness," opened states to varying levels of change that made authoritarian restoration, democratic transition or state failure possible, even likely, but not necessary.

\section{The Direction of Governance Change}

The second dimension of state trajectories is emergent differences in governance or regime type. This was partly shaped by the way initial struggles between opposition mobilization and regime resilience started states on different trajectories; however, trajectories were further shaped by the post-Uprising interaction of rival social forces promoting differing governance preferences and structural constraints that biased the struggle in favour of some and against other social forces.

Post Uprising Balance of Agency: the emergent power balance among forces contending to shape the new order among rival social forces--revolutionary youth, organized workers, Islamists, and proregime forces--helped determine whose post-Uprising governance preferences would prevail. Also important is their ability to form coalitions, including pacts between regime and opposition.

International Intervention: The "competitive interference" of rival powers in Uprising states affected trajectories: the less competitive interference the better chance of peaceful transition to democracy; the greater the interference, the greater the chances of state failure.

Political Economy, including development strategies (i.e. import substitution, agricultural export), constitutes the deeper structures that determine regimes' political inclusion and exclusion of social forces. Middle East and North Africa (MENA) political economy heritage, which empowers the state and crony capitalists, biases outcomes against democratization, which requires a fairly rare balance of class power; but variations in how far some balance exists matter for regime trajectories. 


\section{Reconstituting Authority: the Variability of Governance Outcomes}

Three different post-uprising trajectories emerged-- 1) democratization; 2) authoritarian restoration and 3) failing states. Failing states varied from those where central government totally collapsed (Libya) to cases of partial state failure where the regime lost its monopoly of violence and control over only parts of its territory (Syria).

In each of these scenarios, the post-Uprising reconstitution of authority took quite different forms. In failed states, "competitive state remaking" took place as elites and counter-elites reproduced historically "successful" "Khaldunian" practices: regime remnants re-constituted themselves in more violent forms of neo-patrimonialism opposed by equally violent charismatic movements. Where states did not fail, democratization was possible if opposition social movements were able to establish inclusive political institutions (assemblies, parties), able to balance bureaucratic authority. Alternatively, authoritarian restoration came about when a hybrid of patrimonial and bureaucratic authority marginalized such movements.

\section{Explaining Variations in Post-Uprising Trajectories}

\section{The Depth of Change}

Social Structure and Variable Mobilization: Unleashing Contestation, Opening Political Space

Variations in the intensity and breadth of anti-regime mobilization determine whether enough political space was opened to make regime change possible and whether anti-regime movements were able to build the cross-class/cross-communal alliances needed to create winning coalitions. Social movement theory (SMT) attributes such variations (Leenders 2013; Dupont and Passy 2011) to movements' capacity to exploit grievances, thereby de-legitimizing the status quo, and to whether the political opportunity structure facilitates or obstructs the mobilization of these grievances.

Although anti-regime grievances were ubiquitous, variations among states in their intensity affected the ability of movements to mobilize discontent. Thus, in Egypt and Tunisia large cross-class coalitions involving revolutionary youth, union activists, Islamists and the urban poor joined to overwhelm by sheer numbers the very substantial security forces and converged on the centre of power while no social forces-even the constituents of the large ruling parties--seemed prepared to defend the incumbent presidents who were forced out of power (Tripp 2014: 95; Ghobashy 2011) in what could be called bandwagoning mobilization. By contrast in Syria, Libya, Yemen and Bahrain there was enough mobilization to destabilize the state but regimes had core constituencies prepared to defend them and wider groups were unwilling to bandwagon with the opposition, obstructing the irresistible mobilization needed to sweep away incumbent rulers--what might be called balanced mobilization. What explains these variations? The improved political opportunity structure resulting from factors such as the use of the internet to overcome the atomization of society has been stressed to understand why the Uprising happened in 2010-11 and not before, even though grievances had been in existence for decades. However, variations in mobilization across the uprising states were most powerfully conditioned by variations in social structure--depth of class grievances/cleavages which drive mobilization and whether or not there are cross-cutting communal cleavages which dilute it.

Class grievances were a product of the regimes' evolution from inclusionary populist authoritarianism to post-populist exclusionary versions under the impact of global neo-liberalism. Both growing class inequality and a perception that opportunities were limited to regime cronies generated a potent cocktail of grievances that exploded in the Uprising. As such, other things being equal, the earlier post-populism began, hence the more advanced it likely was, the deeper the class inequalities, the more intense the accumulation of grievances and the more widespread mobilization was likely to be. In MENA the move to post-populism was most advanced in Tunisia and Egypt which had pioneered it in the 1970s, while in Syria, where it came three decades later, its impact would likely have been lesser: the lifting of key subsidies, e.g. on diesel fuel used by peasants for irrigation, only began to negatively affect the lower strata in the second half of the 2000s while similar measures in Egypt, notably the rollback of the agrarian relations law depriving peasant tenants of secure tenure, had been generating rural grievances for decades. Levels of inequality appear to have been higher in Tunisia than Egypt because of its yet earlier embrace of neo-liberalism. Indicative of this, in the late 1990s, the gini index of inequality was $33.7 \%$ in Syria, 37.4\% in Egypt and 41.7\% in Tunisia (Bibi and Nabli 2010)

However, populations are often divided not just by class inequalities but also by communal (sectarian, ethnic, tribal) cleavages, mirrored in a fragmented civil society. Normally fragmentation dilutes mobilization on both class and communal grounds. In Egypt and Tunisia weak communal cleavages were no obstacle to cross-class mobilization. If communal and class cleavages are reinforcing, perhaps because a particular communal group holds disproportionate power, the belief that regimes discriminate on communal grounds is likely to intensify socio-economic grievances. However, where 
communal cleavages cross-cut class, with, e.g. a cross-communal upper class benefiting from postpopulism while retaining clients in the lower classes, as in Lebanon, mobilization against the regime would be limited or divided into pro and anti-regime movements (balanced mobilization). Syria was a middle case where a coalition of middle class anti-regime activists and the rural poor victimized by postpopulism (and feeling discriminated against on sectarian grounds), produced enough mobilization to destabilize the regime, but not to overthrow it. This is because a substantial portion of the Sunni urban upper and middle strata, particularly beneficiaries of post-populism, and the religious minorities aligned with the minority (Alawi) dominated regime or (Kurds) at least did not join the opposition coalition, producing balanced mobilization).

Variations in levels of mobilization help determine the consequent degree of political openingthat is whether incumbent presidents were forced to depart, starting possible democratic transition (Egypt, Tunisia) or the movement peters out with little significant change (Lebanon, Bahrain) or else mobilization is enough to destabilize the regime/state but not for the opposition to take or consolidate power, putting the country on the slippery slope to civil war and state failure (Syria, Yemen, Libya).

\section{Neo-Patrimonial Variations and Regime/State Resilience}

Regime's variable capacity to resist change is also important to understanding outcomes and to understand this we need to turn to Weberian analysis. Classical political sociology's "iron law of oligarchy" demonstrated the big asymmetry of power between elites, who are normally unified and control levers of bureaucratic command, compared to the normally fragmented and passive masses. Indeed, MENA's republics were all neo-patrimonial hybrids of patrimonial and bureaucratic authority that seemed to exemplify the iron law: presidents' personalistic authority, buttressed by intra-elite assabiya, fostered elite cohesion while bureaucratic command afforded infrastructural power over society (Mann 1984). However, if, in "abnormal" times, significant anti-regime mobilization encounters--or causes--elite disunity and/or debilitates bureaucratic capacity, reversing pro-elite power asymmetries, space may be opened for regime transition. The pre-existing configuration of authority partly determined whether elites in the uprising states remained cohesive or split and whether bureaucratic institutions absorbed enough constituents to dilute bandwagoning mobilization or were overwhelmed by it. A number of distinct scenarios unfolded, in good part determined by the impact of the interrelation of patrimonial and bureaucratic authority on elite cohesion and bureaucratic capacity

In many republican cases uprising mobilization was sufficient to split ruling elites, but outcomes varied according to the bureaucratic-patrimonial balance. Where bureaucratic authority of office was relatively developed compared to the president's personal authority, leadership transition could be initiated without risking state failure. Specifically, where, as in Tunisia and Egypt, the army high command had a degree of autonomy of the president and was not colonized by a particular identity group, state elites could sacrifice the president to save themselves without imperilling the regime (Stepan and Linz, 2013; Stacher 2012: 39, 158) and elite splits could be contained at the central level without unravelling the state. In such scenarios, the jettisoning of authoritarian presidents allowed for elite circulation and opened a possibility of democratic transition. On the other hand, if the patrimonial side of regimes had, pre-uprising, debilitated the bureaucratic integrity of institutions and if at the same time intra-elite asabiyya failed to prevent elite splits, elite factions' rival clientele networks would tend also to split the military and bureaucracy, possibly leading to state failure, as seen in Libya and Yemen.

Bahrain and Syria were the only cases where the ruling elites did not fracture under mass antiregime mobilization. In Bahrain the solidarity of the ruling family, readily-controlled small geographic space, and GCC intervention quickly ended the uprising. In Syria, the personal authority of the president helped contain elite factionalism and his clientalization of the security forces also helped minimize defections when it was called upon to use force against protestors. Elites remained cohesive behind the president; but, at the same time, the relative diffusion of power among core elites entrenched in rival bureaucratic institutions (party, army, security forces) meant nobody had the power to decide on a swift transition or could move against the president without imperilling the whole regime (Stacher 2012).

At the same time, bureaucratic capacity mattered for trajectories. Regimes' ability to contain the intensity of anti-regime mobilization depended on the balance between mobilization and their institutional capacity to incorporate social forces. The more socially mobilized the society, the more developed this capacity had to be both in terms of organizational capacity, specifically inclusion in party and syndicalist organization, and in terms of possessing co-optative resources (such as oil rent). The more social mobilization exceeded political incorporative capacity, the more regimes were vulnerable to anti-regime political mobilization; in Tunisia, relatively high levels of social mobilization were politically unincorporated by Ben Ali's exclusionary ruling party, helping to explain the bandwagoning mobilization that led to the quick overthrow of the president.

Regimes' ability to avoid state failure amidst uprisings, to resist longer-term insurgencies and to stabilize post-Uprising regimes depended on whether the state apparatus enjoyed institutional capability such as infrastructural penetration of society via the bureaucracy. This was, to some extent, a function of 
variable histories of state formation. Thus, where, as notably in Egypt and Tunisia, the uprising power struggle took place within a polity with a substantial history of statehood - "stateness" --hence robust identification with the state as well as a long tradition of bureaucracy, it was less likely to result in state failure. Where the state was recent, with boundaries externally imposed and contested by strong rival sub and supra-state identities, as in Syria, the state was more vulnerable and, to a considerable extent, held together by the regime, making it therefore vulnerable to collapse to the extent the regime was weakened. However, this can be compensated for: thus, the Syrian regime had developed, and retained amidst the uprising, fairly robust bureaucratic capabilities (with its strong single party and military) and its ability to withstand years of post-Uprising anti-regime mobilization was partly due to this. By contrast, in Libya and Yemen these were much weaker. Qaddafi had deliberately debilitated the state, including the army, while in Yemen state infrastructural power was obstructed by tribalism. Thus, bureaucratic capabilities varied considerably from relatively high in the case of Egypt and Tunisia, to minimal in Libya, explaining differing vulnerabilities to state failure.

\section{The Interaction of Anti-regime Mobilization and Regime Resilience}

In summary, regime capacities interacting with mobilization levels explain how states were set on different trajectories at the outset of the uprising. Where mobilization remained low, it was easily contained by relatively bureaucratized regimes (Algeria) and even patrimonialized ones could survive, e.g. Jordan. Where, conversely, high mobilization produced anti-regime bandwagoning, but inherited "stateness" and bureaucratic capacity was high relative to patrimonial authority, (Tunisia and Egypt), leadership change opened the door to possible democratic transition without risk of state failure. Where the patrimonial side is high and the bureaucratic low (with the leader's clientele networks stronger than state institutions and identification with the state), if regime cohesion fractured under significant antiregime mobilization (even if balanced by some pro-regime mobilization), the state may also fail totally as in Libya and perhaps Yemen. Where balanced mobilization took place and asabiyya kept the regime cohesive, as in Syria, while bureaucratic state institutions were too strong (in spite of colonization by the regime's sectarian [Alawi] in-group) to be overthrown by the opposition but too weak to retain control of the whole territory of the state, the door was opened to partial state failure.

\section{The Variable Directions of Change:}

\section{Transition to Where? The Balance of Power Among Social Forces}

When anti-regime mobilization opens political space, it precipitates a power struggle that further shapes subsequent trajectories. The balance of agency between rival social forces in this struggle, such as civil society movements, Islamist movements, workers unions and the military, will be decisive for the direction of trajectories. This balance of agency is determined by such factors as whether societal forces can constitute themselves as cohesive agents, notably as political parties with the organization to incorporate wider social forces needed to win power and govern. Also important is whether opposition movements--Islamists, secular middle-class activists and workers--can overcome their differences and form democratic coalitions able to bargain on a peaceful pacted transition with soft-liners in the regime or whether they fall out, enabling regimes to co-opt one against the other.

Anti-Regime Democracy Movements: Secular middle-class youth with their Internet proficiency were instrumental in overcoming atomization and enabling anti-regime mobilization in the Arab Uprising states. They were the vanguard of movements that forced the departure of authoritarian leaders and/or won potentially democratic constitutional changes. However, they proved unable to capitalize on the fall or weakening of old regimes (Durac 2015). Their lack of unified ideology and organization meant they could not mobilize empowering mass votes. Leaderless, highly heterogeneous, they quickly divided into contentious factions. In Egypt and Morocco secular liberals' inability to compete with the Islamists in elections quickly compromised their commitment to democracy and revived the ability of the regime to use them against the Islamists. Only in Tunisia did secular forces remained united enough to both balance and compromise with Islamists. In cases such as Syria and Yemen, the fragmentation of the movements meant they could not reach any kind of pacted transition with incumbent rulers and, as a result, soon became armed factions, or gave way to more militant jihadists, propelling state failure and much reducing the prospects of a democratic outcome.

Islamists: The weakening of regimes opened the door to Islamist movements but which variant held the upper hand was crucial for outcomes. Initially the Muslim Brotherhood's modernist Islam appeared empowered by the removal of authoritarian presidents. It had a decisive advantage over secular rivals owing to its activist followings, electoral experience, charity networks, schools and TV stations, welfare services; ability to speak for the deprived; and competitive advantage (over secular opposition) from use of mosques and madrassas for recruitment. In Tunisia and Egypt Islamists got pluralities in the first democratic elections, but not solid majorities that would have been needed to marginalize opposition and govern effectively (Heyderian 2014: 95-110; Lynch 2012: 146-59). Salafists were also energized and propelled into the political arena by the Uprising and by funding from Saudi 
Arabia, which saw them as an instrument against both the Brothers and secular revolutionaries. The behaviour of the Brothers in Egypt where, outflanked and pushed right by the Salafists, they broke several promises not to push their agenda too far, alarmed secularists who aligned against them with the old regime, enabling authoritarian restoration under al-Sisi. Egypt's exclusion of the Brotherhood, an Islamist movement willing to play by democratic rules, with a mass constituency, and the greatest capacity among social forces to balance the power of the state and confer legitimacy on market capitalism, meant no democratic transition was possible. Tunisia was the exception where the ability of secularists and the Islamist al-Nahda to share power enabled Tunisia's democratic transition. The decline of modernist Islamists elsewhere shifted the intra-Islamist balance of power to trans-state jihadist movements inspired by al-Qaida which found new opportunities in failed states resulting from civil war, as was exemplified in Syria (Volpi and Stein 2015).

Workers (in alliance with the salaried middle class) are crucial to the democratic coalition that is needed to drive and consolidate democratization. Aschar (2013: 152-99) observes that they constituted the real alternative to the other two main post-Uprising contending forces, the military/state establishment and Islamist movements, both of which stood for variations of the neo-liberalism against which the uprisings initially mobilized. The marginalization of organized workers during the Uprisings in Syria, Libya and Yemen was a factor in both state failure and democratic failure (Allinson 2015). Where workers movements were, as a result of greater industrialization, larger and better organized, as in Egypt and Tunisia, they played key roles in anti-authoritarian mobilization. Workers' unions were pivotal in the mobilization against the president in Tunisia while in Egypt their nationwide strike action made it clear to the Egyptian military that opposition to Mubarak was too deep and widespread to be rolled back. Yet here the countries parted company: while unions in Tunisia helped broker a compromise between secularists and Islamists, in Egypt they joined the military against the Islamists. The former led to democratic transition, the latter to authoritarian restoration.

Pro-Regime Forces: Regimes, although sharply challenged by opposition social forces in the course of the Uprising, nevertheless survived and launched a fightback. While bureaucracies, crony capitalists and ruling parties were important elements in regimes' resilience, the most immediate determinant of outcomes were the military and security forces. Military responses to the Uprisings varied depending on factors such as the institutional autonomy, repressive capabilities, and interests (political, economic, communal, professional) of military establishments. Initially, seeing the rapid departure of presidents in Tunisia, Egypt and Yemen, many judged that political mobilization had exceeded the repressive containment powers of the old regimes; however, the military and security forces re-grouped, restoring some of the old state-society (im)balance. Joshua Stacher (2015) observed that while states may have been weakened by the Uprising, regimes, and particularly their coercive cores, not only survived but also dramatically expanded the use of violence to rescue old orders.

Variations in the military's role were pivotal for outcomes (Barany 2011; Bellin 2012). In Egypt, where the military retained institutional autonomy of the top political leadership and also had conflicts of interest with the presidential family as well as a large stake in the preservation of the establishment, including control of large sectors of the economy, the high command sacrificed the president to preserve its interests and the institutions of the state. Its dependence on Western financial support also made it unwilling to risk such funding via mass repression on behalf of the president. Once Mubarak departed, Egypt's large politicized army attempted to retain command of the transition process and steer it in such a way as to preserve its interests. It did not hesitate to repress protestors when they targeted its own interests and particularly in its attacks on the Muslim Brothers after al-Sisi's coup it showed that an institutionalized US-funded military was no less willing than patrimonial leaders to use massive violence to defend its own vital interests. Moreover, it possessed the repressive capacity to reassert control over Egyptian society and territory (even if contested in Sinai). This was pivotal in enabling restoration of much of the old order. By contrast, in Tunisia the limited repressive capacities and de-politicization of the military was decisive for enabling democratic transition. The balance among the bureaucratic pillars of the regime also mattered: where, as is usual in MENA, the military was the main state pillar, democratization was less likely; Tunisia was an exception, where the nationalist independence party (The Neo-Destour Party) was, together with the trade unions, the main forces on which the state was built, preempted the military's more usually dominant role in MENA republics. In Syria, sectarian penetration and Ba'thist politicization of the military reduced its autonomy, keeping the bulk of it loyal to the regime. Identity differences between Alawi elements of the security forces and protestors much reduced the chances of defections from the former when they were ordered to fire on civilians. The Syrian military retained enough institutional cohesion to defend the regime from collapse; yet incremental but accelerating individual defections acquired enough critical mass to staff a rival "Free Syrian Army," leading to militarized civil war and partial state failure.

The Balance of Social Forces: Differences in the balance of agency among social forces and coalitions between them drove different trajectories. Generally, peaceful democratic transition requires a pact between soft-liners in the regime and in the opposition while hardliners on both sides may well 
produce civil war. But the relative power of actors biases the kinds of coalitions likely. Where prodemocracy social movements and organized workers were strong, the military weak or non-political, and Islamists moderate, chances for a pacted transition to polyarchy were best (Tunisia). Where the military was strong and politicized while Islamists, democracy movements and workers' unions were divided from each other, ruling establishments combined coercion with divide and rule to co-opt secularists against Islamists and push authoritarian restoration (Egypt); a strong military, radicalization of Islamists, and weakened democracy movements and worker unions and hard-line dominance on all sides biased the outcome toward state failure and civil war (Syria).

\section{The International Variable:}

HS, particularly as exemplified in the work of Tilly (1990), shows how states and states systems coconstitute each other as the international power struggle incentivizes the centralization of power and mass mobilization needed for effective war-making. The international power struggle can also take the form of attempts by states to export or sustain political systems similar to their own through various means from soft power to proxy wars. The main impact of the international variable on regime trajectories in Arab Uprising states was the competitive interference by which rival regional powers used money, propaganda and arms to shift the internal power balance in uprising states in favour of friendly forces: Iran, Saudi Arabia, Qatar, and Turkey backed warring sides and alternative governance models; the Sunni GCC powers and Turkey, themselves split over support for rival kinds of Islamists, and Iran, deployed sectarian polarization against each other. Moreover, both sides used rent transfers during the uprisings to bolster anti-democratic forces--the military in Egypt, the Asad regime, Salafists, and the nonoil monarchies, (Jordan, Morocco). Where neither side able was to sweep the board, the result was both the de-stabilization of states and the fragmenting of publics between secularists and varieties of rival Islamists. The resulting norm fragmentation meant democracy had little chance of becoming "hegemonic" in the region (Hinnebusch 2015). At the global level, the West's democracy export campaign helped delegitimize authoritarian regimes, while authoritarian (or semi-authoritarian) regimes supported each other against this; this was manifest in US and Russian intervention on opposite sides of the Syrian conflict.

The more a country became an arena of interference by regional and global power, the less likely was democratic transition and the more likely state failure. Thus, the most extreme and one-sided form of intervention, that in Libya, resulted in the most total state failure. In Syria, which unlike Libya enjoyed external supporters, the resulting "balanced" or competitive external intervention" on opposing sides empowered both the remnants of the regime and emerging opposition "counter-regimes," albeit only enough to checkmate each other. This prevented authoritarian restoration by the regime and entrenched civil war, with the outcome partial state failure. In Egypt, a moderate level of intervention (Saudi/UAE vs. Qatari financial support for rival sides) was not enough to cause state failure but enough to enhance regime coercive and co-optative capabilities and facilitate authoritarian restoration. Finally, in Tunisia, relatively low interference was compatible with both the survival and democratization of the state.

\section{Structure over Agency: Political Economy}

Political economy structures and development strategies shape the political inclusion and exclusion of social forces that give regimes their essential character. According to Moore (1966) agricultural export strategies require inclusion of land/capital and exclusion of labour, often producing "authoritarianism of the right". By contrast, statist Import Substitution Industrialization (ISI) tends to exclude landed elites and incorporate workers, sometimes under a populist "authoritarianism of the left". Democratization requires special conditions: a balance of social power between the state, the bourgeoisie and the organized working classes (Rueschemeyer, Stephans and Stephans, 1992) and a democratic coalition of the bourgeoisie, the salaried middle and the working classes able to pressure state elites. In this regard, the varieties of capitalism matter; Fordist Keysian capitalism in the period of "embedded liberalism" was expansive and relatively inclusive of both capital and labour and compatible with substantive democracy; the neo-liberal version promoted under globalized finance capitalism generates profound inequalities and sharply tilts the power balance against labour (Cavatorta 2010). It is compatible at best with what Robinson (1996) called "low intensity democracy"-a purely procedural democracy in which the big substantive issues of wealth distribution are removed from the political agenda--and at worst with some sort of authoritarianism in which popular demands are repressed.

In MENA the political economy is doubly unfavourable to democratization and favourable to authoritarianism. First, rentier states produce state-dependent bourgeoisies, clientalized citizens and, in many cases, readily expelled expatriate labour. Indeed, the Gulf monarchies with their copious rent and use of imported non-citizen labour, proved most resistant to the Uprising. Second, the export of neoliberalism to MENA, backed up by the IMF's loan conditionality, shifted the balance of social power against labour and precipitated a transformation from populist to post-populist authoritarianism, abandoning ISI. Economic globalization is co-constituted in the MENA region by local states in the 
distinctive form of crony capitalism, which obstructs democratization. This is because the state--crony capitalist coalitions to exclude labour, parallel with deepening dependencies on global finance capital (and its demands for austerity for the masses), drive a wedge between bourgeoisie and workers; this obstructs the "democratic coalition" between them that is best situated to extract democratization from the state (Guazzone and Pioppi 2009).

The Uprisings did not alter this reality; indeed, although they were rooted in protest at the neoliberal post-populist transformations of the authoritarian republics, as Aschar (2013) observed, they remained purely political, with little attempt to attack economic injustice or inequality; indeed, the Uprisings, in disrupting economic growth, and actually deepening dependence on the Western-centred international financial system, further locked Tunisia and Egypt, the two states with the best prospects for democratization, into neo-liberal practices that made it impossible to address inequality and poverty. This is compatible at best with low intensity democracy, as in Tunisia. Moreover, where the state enjoys rent (provided to post-Mubarak Egypt by Gulf states), it is more likely that it can sustain its coalition with crony-capitalists, less likely that it needs to reach a democratic bargain with workers and more likely to engineer an authoritarian restoration.

\section{Reconstituting Authority: Variable Governance Outcomes}

The final dimension of Uprising trajectories is the reconstitution of authority in their aftermath. Outcomes vary along two dimensions: 1) levels of state consolidation or failure and 2) regime type. As HS tells us, state formation has historically been accompanied by major violence between would-be regimes and their opponents (Tilly 1990) and rested on establishment of a monopoly over its use. Uprisings have tested regimes' monopoly of violence while authoritarian restoration has involved enhanced use of violence by regimes. Where uprisings resulted in state failure-the loss of such a monopoly of violence over territory--state re-formation involved what has been called competitive state re-making (Jones 2008).

But what explains how a monopoly of violence is established? Max Weber, building on Ibn Khaldun, identified the paths to authority creation in MENA, namely charismatic, patrimonial, and bureaucratic authority, expecting that the most successful regimes would be hybrids of his authority types (Zubaida 2011). Acknowledging that path-dependency shapes reproduction of historical practices is not to deny that social movements can alter inherited political culture, e.g. in breaking fear barriers to participation and establishing more demanding notions of legitimacy. And, while none of Webers' historic forms of authority is democratic, per se, variations in them do matter for levels of inclusion of social forces in new regimes: thus, charismatic movements widen mass inclusion which can be institutionalized in political parties and assemblies to which leaders are accountable while bureaucratic authority of office checks arbitrary power and its merit recruitment democratizes access to it; hence, they, unlike patrimonial authority, are compatible with democratization. However, with the Tunisian exception, the MENA outcome has either been restoration of regimes mixing more coercive authoritarian practices with inclusion of some parts of society in order to exclude others (Egypt), or where states failed, charismatic Islamic movements mobilized armed activists while regime remnants evolved into more coercive versions of neo-patrimonial authority. Regimes were, Tunisia aside, more exclusionary than before the Uprising began (Stacher 2015, Heydemann 2013).

\section{Case Studies: Variable Outcomes}

The following seeks to show how the differing configurations of the variables discussed above have led to three distinct trajectories in post-Uprising MENA, as illustrated by three country cases and summarized in Table 1.

\section{Syria: failed transition, failed state}

Conditions for democratic transition were not favourable in Syria: identity fragmentation and the lack of a class balance weakened society, while a robust combination of both patrimonial authority and bureaucratic institutions gave the regime exceptional resilience. The soft-liners were marginalized on both sides by the regime's use of violence and the maximalist demands of the opposition, precluding a peaceful democratic transition. Owing to the cross cutting of class inequalities by urban-rural and sectarian cleavages, and the willingness of the loyal military, partly due to identity cleavages between them and protestors, to use violence against the uprising, opposition mobilization was insufficient to overthrow the regime but enough to deprive it of control over wide parts of the country. Defections from the military were sufficient, together with high levels of external intervention, to militarize the conflict, resulting in protracted civil war and a partly failed state. This empowered anti-democratic agents-the military, jihadists--while pro-democratic forces-the protesting youth, the trade unions--were marginalized. The Uprising greatly sharpened identity cleavages along both sectarian and secularIslamist lines: the breakdown of order stimulated a "security dilemma" in which rival identity groups saw 
the other as the enemy and a war economy was fuelled by rival trans-state funders that gave war lords on both sides a stake in the continuance of the conflict. To fight civil war, the regime reconstituted itself as a more violent and exclusionary form of neo-patrimonialism but with enough bureaucratic capabilities to keep control over a majority of the population; while charismatic insurgents led rival attempts at state reformation in opposition controlled areas. In both cases, the population was included and excluded on identity grounds. This locked Syria into a protracted crisis for at least the immediate future (Saouli 2015).

\section{Egypt: reversed transition}

In Egypt an anti-regime cross-class coalition enabled massive bandwagoning against the ruler; the relative autonomy of the military, which prioritized its own interests, allowed it to engineer presidential departure. In spite of a relatively peaceful transition from Mubarak's rule, the post-Uprising power struggle between secular revolutionaries, the military and Islamists was unconstrained by agreement on rules of the game. The lack of a strong organized pro-democracy movement and autonomous trade unions, compared to the over-sized politicized military, and the split between secularists and divided Islamists allowed a substantial "restoration" of the old regime. Military-led authoritarian restoration depended on sophisticated versions of divide and rule, as exemplified by the military's cooptation of the Muslim Brotherhood to demobilize anti-Mubarak street protests followed by its co-optation of the "Tamarod" movement to destroy the Brotherhood's President Morsi. No democracy that excludes one of the most important socio-political forces in Egypt can be consolidated and only a hybrid regime, retaining extra-constitutional powers for the security forces, can cope with the violent spillover of Islamist resistance. This reflected the lack of a balance of class power able to check a rent-funded state. Indeed, Saudi money played a crucial role in encouraging and supporting the counter-revolution, both in funding the al-Sisi regime and in encouraging its Salafist clients to break with the Brotherhood and support the military. A populist-xenophobic intolerance of dissent more repressive than under Mubarak was combined with electoral authoritarianism manifested in exclusionary or manipulated election, with some groups included in order to exclude others.

\section{Tunisia: transition consolidation}

As in Egypt, cross-class grievances and a favourable opportunity structure--civil society and trade union experience-enabled bandwagoning mobilization against Ben Ali that, given the refusal of an autonomous military to protect the president, enabled an insider-outsider pacted democratic coalition. Tunisia's relative homogeneity and long history of statehood consolidated the political community needed to underpin contestation over other issues. Unlike in Egypt, transition was not reversed. What made the big difference from Egypt were Tunisia's larger middle class, greater mass literacy, robust unionized workers movement, small un-politicized army and a historically more moderate Islamist movement, making compromise with secularists possible. Moderate democratic Islamists (al-Nahda) were much stronger than Salafists and, contrary to the case in Egypt, entered a coalition with secularists rather than the Salafists. Nevertheless, the secularist-Islamist cleavage plunged the country into a crisis in 2013 similar to what was, in parallel, happening in Egypt. However, in contrast to Egypt, there was no "man on horseback" in Tunisia's small politically unambitious military that rival political forces could call upon to "rescue" the country from the other; hence they had to compromise their differences through dialogue which the trade unions brokered. The constituent assembly was more inclusive than in Egypt and was able to reach a compromise constitutional formula. Crucially, the balance of agency favoured democratic forces. The limited role of the military in public life and the exceptional role of the trade union movement in brokering a consensus had its origins in the fact that the independence movement had combined a powerful political party, the Destour, and an equally powerful union movement, pre-empting the role of national vanguard assumed elsewhere, including Egypt, by the army. As a result, Tunisia experienced the most thorough democratization.

\section{Comparing Outcomes}

Thus, immediate post-Uprising outcomes varied significantly in line with differing combinations of the factors discussed above and summarized in Table 1. While in Egypt and Tunisia bandwagoning mobilization against the regime and military autonomy produced relatively peaceful presidential removal combined with state survival owing to considerable pre-existing history of state-centric identity, in Syria cross-cutting cleavages diluted anti-regime mobilization and presidential control of the military precluded a peaceful transition. After the initial uprising, trajectories further diverged according to the balance of post uprising agency. In Tunisia a combination of a weak military, moderate Islamists and strong trade unions-and the ability of Islamists and secularists to compromise their differences-facilitated democratic transition. In Egypt sharp Islamist-secularist conflicts allowed the strong politicized military to engineer authoritarian restoration. In Syria, the combination of a strong military and radical Islamists militarized the conflict which led to the division of state territory and, given relatively weak state identity, precipitated partial state failure. Context also mattered: Tunisia came 
closest to the class balance needed for democratization, given the relative strength of industrialization and organized labour; external rent in Egypt over-empowered the "deep" state; and an externally drive rent-fuelled war economy in Syria furthered civil war. Finally, external intervention in Tunisia was too limited to disrupt democratization; medium levels of intervention (notably, Saudi) facilitated democratic reversal in Egypt; and intense competitive interference in Syria blocked any resolution of civil war, deepening state failure.

\section{Conclusion: The Advantage of "Complex HS"}

This study attempted a systematic comparative analysis of the factors that shaped the main trajectories taken by post-Arab uprising states. While validation of the analysis would require far more documentation and evidence than has been possible to present in this article, it arguably represents a breakthrough which would not have been possible without complex HS. HS enabled us to see that the outcome was a function of a power struggle in which there was no one pre-determined endpoint (such as democracy); rather, the balance between mobilization (shaped notably by variation in social structure) and regime resilience, (shaped notably by the balance between patrimonial and bureaucratic capacities), and the balance between rival social forces in the immediate post-uprising power struggles together shaped quite variable trajectories. Agency clearly mattered but structure allowed us to understand why the cards were stacked for and against the preferences of certain social forces in these struggles: political economy factors, by shaping differing balances of internal social forces, fostered authoritarian restoration in Egypt and low intensity democracy in Tunisia. Finally, intense forms of external interference in uprising states fostered partial state failure in Syria, in which the remnants of regime militaries and armed Islamic movements competed to reconstitute authority. On the whole, these last factors, outside the control of the competing rivals in the uprisings, go far to help us understand why the "harvest" of the uprising was so thin.

\begin{tabular}{|c|c|c|c|}
\hline Variables & Syria & Egypt & Tunisia \\
\hline $\begin{array}{l}\text { MASS MOBILIZATION } \\
\text { Cleavages }\end{array}$ & $\begin{array}{l}\text { Mobilization diluted by cross- } \\
\text { cutting cleavages }\end{array}$ & $\begin{array}{l}\text { Bandwagoning via cross-class } \\
\text { coalitions }\end{array}$ & $\begin{array}{l}\text { Bandwagoning via cross- } \\
\text { class coalitions }\end{array}$ \\
\hline $\begin{array}{l}\text { REGIME CAPACITY } \\
\text { (co-optative and coercive) }\end{array}$ & $\begin{array}{l}\text { Patrimonial-bureaucratic } \\
\text { balance }\end{array}$ & $\begin{array}{l}\text { Patrimonialism } \\
\text { bureaucratically constrained }\end{array}$ & $\begin{array}{l}\text { Patrimonialism } \\
\text { bureaucratically } \\
\text { constrained }\end{array}$ \\
\hline Military role & Low autonomy-loyal to leader & High autonomy & High autonomy \\
\hline $\begin{array}{l}\text { Bureaucratic } \\
\text { territorial penetration }\end{array}$ & Medium & High & High \\
\hline $\begin{array}{l}\text { History of statehood and } \\
\text { shared identity community }\end{array}$ & Low & High & High \\
\hline $\begin{array}{l}\text { POLITICAL ECONOMY } \\
\text { class balance } \\
\text { economy }\end{array}$ & $\begin{array}{l}\text { Lack of class balance } \\
\text { War economy }\end{array}$ & $\begin{array}{l}\text { Lack of class balance } \\
\text { Rentier economy }\end{array}$ & $\begin{array}{l}\text { Some class balance } \\
\text { Productive economy }\end{array}$ \\
\hline EXTERNAL INTERVENTION & High & Medium & Low \\
\hline $\begin{array}{l}\text { AGENCY } \\
\text { Dominant forces and their } \\
\text { relations }\end{array}$ & $\begin{array}{l}\text { military } \\
\text { vs. radical Islamists }\end{array}$ & $\begin{array}{l}\text { military vs. moderate } \\
\text { Islamists }\end{array}$ & $\begin{array}{l}\text { moderate Islamists + } \\
\text { trade unionists +civil } \\
\text { society }\end{array}$ \\
\hline OUTCOME & Partially Failed State & Hybrid regime & Polyarchy \\
\hline
\end{tabular}

\section{References}


Aarts, Paul, Peter van Dijke, Iris Kolman, Jort Statema, Ghassan Dahhan. 2012. From Resilience to Revolt: Making sense of the Arab Spring. (Amsterdam: University of Amsterdam).

AbuShouk, Ahmad Ibrahim. 2016. "The Arab Spring: A Fourth Wave of Democratization?," DOMES, Digest of Middle East Studies, 25: 1, 52-69

Allinson, Jamie. 2015.“Class Forces, Transition and the Arab Uprisings: A Comparison of Tunisia, Egypt and Syria," Democratization 22 (2).

Aschar, Gilbert, 2013. The People Want: a radical exploration of the Arab Uprising. London Saqi Books.

Barany, Zoltan. 2011. "Comparing the Arab revolts: The Role of the Military." Journal of Democracy, 22 (4), 28-39.

Bellin, Eva. 2012. "Authoritarianism in the Middle East: Lessons from the Arab Spring," Comparative Politics, 44 (2), 127-149.

Bibi, Sami and Mustapha K Nabi. 2010. Equity and Inequality in the Arab Region. Cairo: Economic Research Forum, Research Report 33, February.

Brownlee, Tarek Masoud, and Andrew Reynolds. 2013. "Why the Modest Harvest?" Journal of Democracy, Volume 24(4), 29-44.

Brynen, Rex, Pete Moore, Bassel Salloukh, Marie-Joelle Zahar. (2012). Beyond the Arab Spring: authoritarianism and democratization in the Arab world. Boulder CO: Lynne Rienner Publishers.

Cavatorta, Francesco. 2010. "The Convergence of Governance: Upgrading Authoritarianism in the Arab World and Downgrading Democracy Elsewhere?" Middle East Critique, 19 (3), 217-232.

Dupont, C. and Passy, F. 2011. "The Arab Spring or How to Explain those Revolutionary Episodes?" Swiss Political Science Review, 17: 447-451. doi:10.1111/j.1662-6370.2011.02037.x)

Durac, Vincent. 2015. "Social Movements, Protest Movements and Cross-Ideological Coalitions - the Arab Uprisings Re-appraised." Democratization, 22 (2).

Guazzone, Laura and Daniella Pioppi. 2009. The Arab State and Neo-Liberal Globalization, Cairo: American University in Cairo Press.

Ghobashy, Mona. 2011. “The Praxis of the Egyptian Revolution”, Middle East Report, 258, www.merip.org/ mer/mer258/praxis-egyptian-revolution, accessed 15 September 2014.

Heydemann, Steven. 2013. "Syria and the Future of Authoritarianism," Journal of Democracy. 24(4), 59-73

Heyderian, Richard Javad. 2014. How Capitalism Failed the Arab World: the economic roots and precarious future of the Middle East Uprisings, London: Zed Books.

Hinnebusch, Raymond. 2014. "Historical Sociology and the Arab Uprising," Mediterranean Politics. 19(1), 137-140.

Hinnebusch, Raymond. 2015. "Globalization, democratization and the Arab uprising: the international factor in MEN's failed democratization, Democratization. 22 (2), 335-357.

Hinnebusch, Raymond. 2016. After the Arab Uprisings: between democratization, counter-revolution and state failure. London: Routledge.

Huntington, S.P. 1968. Political Order in Changing Societies. New Haven: Yale University Press.

Jones, Seth. 2008. “The Rise of Afghanistan's Insurgency: State Failure and Jihad, International Security, 32 (4), 7-40. 
Leenders, Reinoud. 2013. "Social Movement Theory and the Onset of the Popular Uprising in Syria". Arab Studies Quarterly 35 (3), 273-289.

Leenders, Reinoud. 2016. "Arab regimes' International Linkages and Authoritarian Learning," Toward an Ethnography of Counter-revolutionary Bricolage," Project on Middle East Political Science, http://pomeps.org/2016/07/14/arab-regimes-international-linkages-and-authoritarian-learningtoward-an-ethnography-of-counter-revolutionary-bricolage/

Lynch, Marc. 2012. The Arab Uprising: the unfinished revolutions of the new Middle East, NY: Public Affairs

Mann, Michael. 1984. "The Autonomous Power of the State: its Origins, Mechanisms and Results." European Journal of Sociology/Archives Européennes de Sociologie, 25(02), 185-213.

Michels, Robert. 1966. Political Parties: A Study of the Oligarchical Tendencies of Modern Democracy. New York: Free Press.

Moore, Barrington. 1966. The Social Origins of Dictatorship and Democracy. Boston: Beacon Press.

Mosca, Gaetano. 1939. The Ruling Class, NY: McGraw-Hill.

Robinson, William I. 1996. Promoting Polyarchy: Globalization, US Intervention, and Hegemony, New York: Cambridge University Press.

Rueschemeyer, Dietrich, Evelyne Huber Stephens, and John D Stephens. 1992. Capitalist Development and Democracy. Cambridge: Polity Press.

Saouli, Adham. 2015. "Back to the Future: The Arab Uprisings and state (re) formation in the Arab World," Democratization, 22(2), 315-334.

Stacher, Joshua. 2012. Adaptable Autocrats: regime power in Egypt and Syria, Stanford, CA: Stanford University Press.

Stacher, Joshua. 2015. "Fragmenting states, new regimes, militarized state violence and transition in the Middle East," Democratization, 22(2), 259-75.

Stepan, Alfred. and Juan Linz. 2103. "Democratization Theory and the 'Arab Spring'." Journal of Democracy $24(2), 15-30$

Tilly, Charles. 1990. Coercion, Capital, and European States, AD 990-1990. Cambridge, MA: B. Blackwell.

Tripp, Charles. 2014. The Power and the People: paths of resistance in the Middle East. Cambridge: Cambridge University Press.

Valbjorn, Morten. 2015. "Reflections on Self-Reflection - On framing the analytical implications of the Arab uprisings for the study of Arab politics." Democratization, 22(2), pp. 218-32.

Volpi, Frederic and Ewan Stein. 2015. "Islamism and the State after the Arab Uprisings: between people power \& state power. "Democratization, 22(2), 276-293.

Zubaida, Sami. 2011. "The 'Arab spring' in historical perspective," Open Democracy, 21 October, Available at http://www.opendemocracy.net/sami-zubaida/arab-spring-in-historical-perspective 